\title{
NUMBER AND SIZE OF MYENTERIC NEURONS OF THE DUODENUM OF ADULT RATS WITH ACUTE DIABETES
}

\author{
MARIA MONTSERRAT D.P. FURLAN*, MARCÍLIO H. DE MIRANDA-NETO**, \\ DÉBORA DE MELLO G. SANT'ANA***, SÔNIA L. MOLINARI****
}

\begin{abstract}
This study had as its purpose to assess the effects of acute diabetes induced by streptozotocin ( 35 $\mathrm{mg} / \mathrm{kg}$ body weight) on the number and size of the myenteric neurons of the duodenum of adult rats considering equally the antimesenteric and intermediate regions of the intestinal circumference. Experimental period extended for a week. Neuronal counts were carried out on the same number of fields of both regions of the duodenal circumference and measurements of neuronal and nuclear areas on equal numbers of cells. Number and size of the myenteric neurons stained with Giemsa were not significantly different between groups. On the other hand, the proportion of NADH-positive neurons increased from $18.54 \%$ on the controls to $39.33 \%$ on the diabetics. The authors discuss that this increased reactivity probably results from a greater $\mathrm{NADH} / \mathrm{NAD}^{+}$ratio, described in many tissues of diabetic animals, which has consequences on the modulation of the enzymes that use these cofactors and whose activity is detected by the NADH-diaphorase technique.
\end{abstract}

KEY WORDS: duodenum, myenteric neurons, acute diabetes, NADH-diaphorase.

\begin{abstract}
Número e tamanho dos neurônios mientéricos do duodeno de ratos adultos com diabetes agudo
RESUMO - Este estudo teve como objetivo avaliar os efeitos do diabetes agudo induzido por estreptozootocina $(35 \mathrm{mg} / \mathrm{kg}$ de peso corporal) sobre o número e tamanho dos neurônios mientéricos do duodeno de ratos adultos considerando de forma equivalente as regiões antimesentérica e intermediária da circunferência intestinal. $\mathrm{O}$ período experimental se estendeu por uma semana. As contagens neuronais foram feitas em igual número de campos nas duas regiões da circunferência duodenal e as mensurações das áreas neuronais e nucleares em igual número de células. O número e o tamanho dos neurônios corados por Giemsa não foram significativamente diferentes entre os grupos. Por outro lado, a proporção de neurônios NADH-positivos aumentou de $18,54 \%$ nos animais controles para $39,33 \%$ nos diabéticos. Os autores discutem que essa maior reatividade possivelmente resultou do aumento da proporção NADH/NAD ${ }^{+}$, descrita em diversos tecidos de animais diabéticos, que repercute na modulação das enzimas que utilizam esses cofatores e cuja atividade é detectada pela técnica da NADHdiaforase.
\end{abstract}

PALAVRAS-CHAVE: duodeno, neurônios mientéricos, diabetes agudo, NADH-diaforase

The knowledge about the mammalian enteric nervous system (ENS) can be considered, currently, as wide and in some instances, quite deep. Descriptions found on the literature assess several aspects of this subdivision of the autonomic nervous system ${ }^{1-5}$ and reveal the richness of structure and organization of this neuronal population of magnitude similar to that of the spinal

Trabalho originado de Dissertação de Mestrado apresentada ao Curso de Mestrado em Ciências Biológicas, área de concentração Biologia Celular, Universidade Estadual de Maringá. Departamento de Ciências Morfofisiológicas, Universidade Estadual de Maringá: *Professora Auxiliar; **Professor Adjunto; ***Professora Ms. Assistente (e Professora da Universidade Paranaense, Umuarama); ****Professora Associada. Aceite: 31-maio-1999.

Dra. Maria Montserrat Diaz Pedrosa Furlan - Departamento de Ciências Morfofisiológicas, Universidade Estadual de Maringá - Av. Colombo 5690 - 87020-900 Maringá PR - Brasil. 
cord $^{6}$. Systematization of the studies on the enteric neurons, especially those of the myenteric plexus of species such as the rat, mouse and guinea-pig, have permitted to determine, with relative precision, the functions of specific groups of neurons ${ }^{7-9}$. Due to the accessibility of the ENS, investigations about the alterations caused by pathophysiological states, such as diabetes, have been equally productive; there are reports on the literature ${ }^{10-13}$ about the differential effects of diabetes on specific neurotransmitter systems and on neurons of diverse intestinal segments.

Among the various approaches used on the study of the neurons of the ENS one of the most common and of good reproducibility is the morphoquantitative approach, i.e., the evaluation of the enteric neurons through neuron counts, measurements and morphological parameters. As these studies proceed, differences are observed between the gastrointestinal segments concerning the number and size of the myenteric neurons ${ }^{6,14,15}$. More recently, it was also found that a single portion of the gastrointestinal tract can show significant neuronal differences among its circumferential regions ${ }^{16-}$ 18. This fact must be considered of fundamental importance on the morphological and quantitative analyses, especially when experimental states are being assessed, once inherent differences of the enteric neurons can be mistaken for pathophysiological differences.

A manner of avoiding this kind of difficulty is to consider, on the morphoquantitative analyses, a single circumferential region of the intestinal segment of interest in all experimental groups. Alternatively, it is possible to take into account two or more regions of the intestinal circumference, as long as they are equally evaluated.

Considering that there are many reports about morphological and quantitative alterations of the myenteric plexus which are caused by diabetes, but that do not take into account the circumferential regionalization of the studied segment(s), this study analyzed the effects of acute diabetes on the number and size of the myenteric neurons of the duodenum of adult rats considering equally the antimesenteric and intermediate regions of the duodenal circumference.

\section{METHOD}

Twenty male Rattus norvegicus, aging seven months, from the Central Biotery of the State University of Maringá, were divided into two groups: group C, control, composed of ten animals weighting $443.6 \pm 3.06 \mathrm{gr}$ and group $\mathrm{D}$, diabetic, composed of ten animals of $437.4 \pm 3.04$ gr body weight. All the animals were initially subjected to overnight fast, but only the animals of group D received i.v. injection of streptozotocin $(35 \mathrm{mg} / \mathrm{kg}$ body weight) in citrate buffer $\mathrm{pH} 4.5$ in the morning. Groups were kept in separate compartments with water and ration ad libitum for one week.

Overnight fast preceeded the sacrifice, so as to facilitate cleaning of the segments. Animals were killed under ethylic ether anesthesia, blood samples were collected for the glucose oxidase test, and laparotomy was carried out.

The duodenum was entirely removed and the excess of mesenteric fat was dissected out. Five segments of each experimental group were washed in $0.9 \%$ saline solution, and filled and immersed in fixative for further staining according to the Giemsa technique ${ }^{19}$. Fixation was, at least, of 48 hours, and staining was carried out for 16 to 20 hours. The other five segments of each group were washed and filled with Krebs solution, $\mathrm{pH} 7.3$, and prepared according to the NADH-diaphorase technique ${ }^{20}$. Segments were kept on the incubation medium for 45 minutes, and fixation in $10 \%$ buffered formol solution lasted for a minimum of 48 hours. Distension of the segments was kept by ligature of the extremities.

For microscope examination, rings of duodenum were opened by the mesenteric margin and the mucosa and submucosa, as well as part of the circular muscle layer, were removed under stereomicroscope. Slide preparation of the resultant whole-mounts followed the routine histological procedure of dehydration and diaphanization.

Neuron counts were carried out on Olympus BX40 microscope under 40X objective. In each wholemount preparation, either those stained by Giemsa or those subjected to the NADH-diaphorase technique, it was counted all neurons seen in 80 microscopic fields, 40 fields on the antimesenteric region and 40 on the intermediate region (Fig 1). Half-seen neurons were counted on alternate fields. Total area of the 80 fields was $17.68 \mathrm{~mm}^{2}$. 


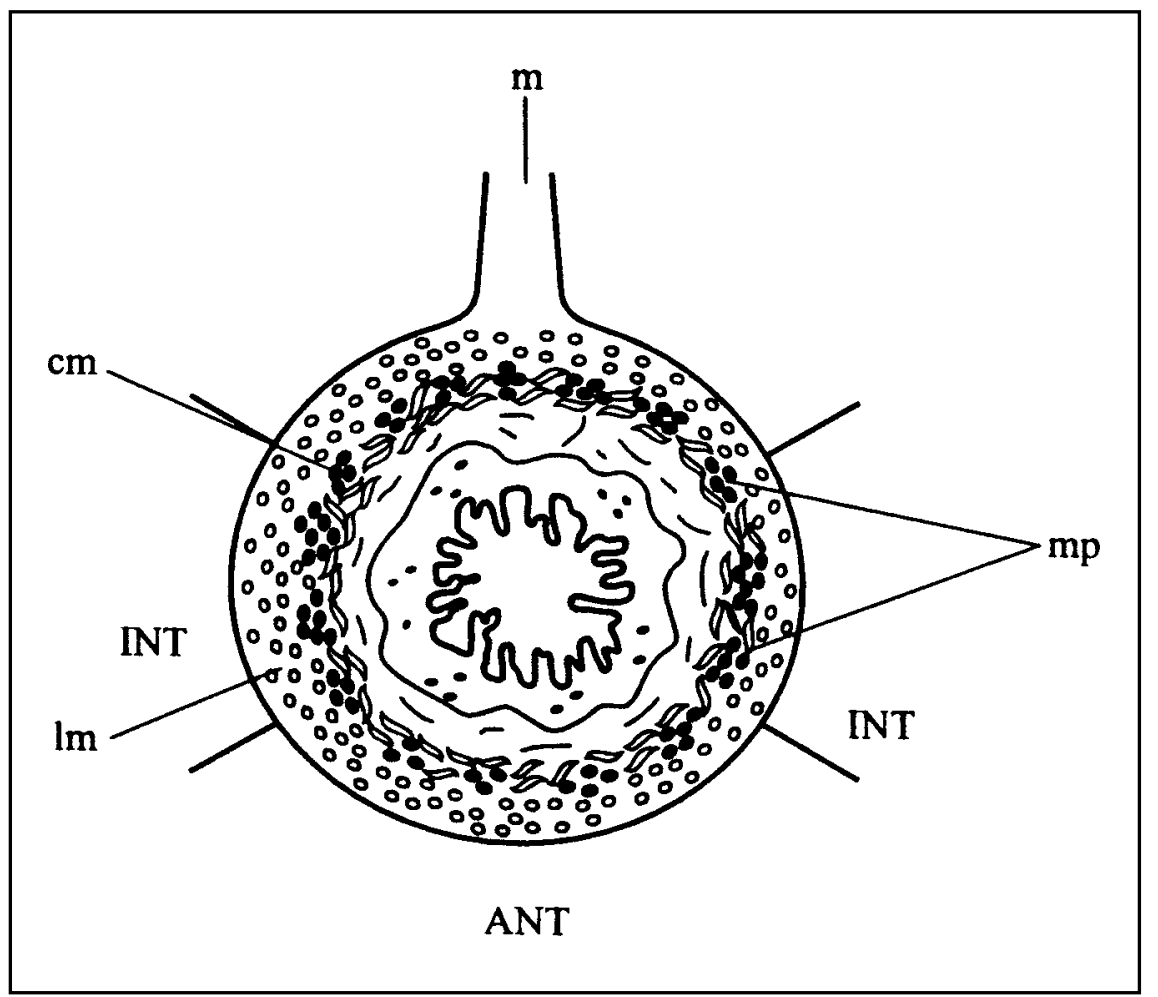

Fig 1. Schematic illustration of a transverse section of the duodenum, depicting the myenteric plexus $(\mathrm{mp})$ between the circular $(\mathrm{cm})$ and longitudinal $(\mathrm{lm})$ muscle layers and showing the antimesenteric (ANT) and intermediate (INT) regions of the duodenal circumference; m: mesenteric atachment.

The proportion of neurons stained by the NADH-diaphorase technique (NADH-positive neurons) relative to the Giemsa-stained neurons was calculated.

Measurements of the areas of cell body and nucleus profiles were made using image analyser (Image-Pro Plus 3.0.1) coupled to the microscope. In each Giemsa-stained whole-mount 100 neurons were measured, 50 in each circumferential region.

Data are presented as mean $\pm \mathrm{SE}$. The two regions were considered altogether, both on the quantitative and the morphological analyses. Comparisons of the results used the single-tailed t test for unpaired data (Prism 2.0) with significance level of $5 \%$.

\section{RESULTS}

Plasma glucose of the control group $(102.0 \pm 4.51 \mathrm{mg} / \mathrm{dl})$ was significantly lower $(\mathrm{p}<0.0001)$ than that of the diabetic animals $(214.4 \pm 9.15 \mathrm{mg} / \mathrm{dl})$. During removal and dissection of the duodenum, alterations of tonus, hypertrophy or hypotrophy of tunicas or lesions were observed in none of the animals.

In $17.68 \mathrm{~mm}^{2}$ of the Giemsa-stained whole-mounts it was found $3615 \pm 62.01$ neurons on the control animals; on the diabetic animals $3460 \pm 123.9$ neurons were counted. The difference between groups did not attain significance $(\mathrm{p}=0.2957)$, in spite of the number of neurons found on the diabetic animals being smaller than that found on the controls.

As for the NADH-positive neurons, it was found in $17.68 \mathrm{~mm}^{2} 670.2 \pm 129.4$ neurons on the controls (Fig 2) and 1361 \pm 181.8 neurons on the diabetics (Fig 3), this being a significantly higher 


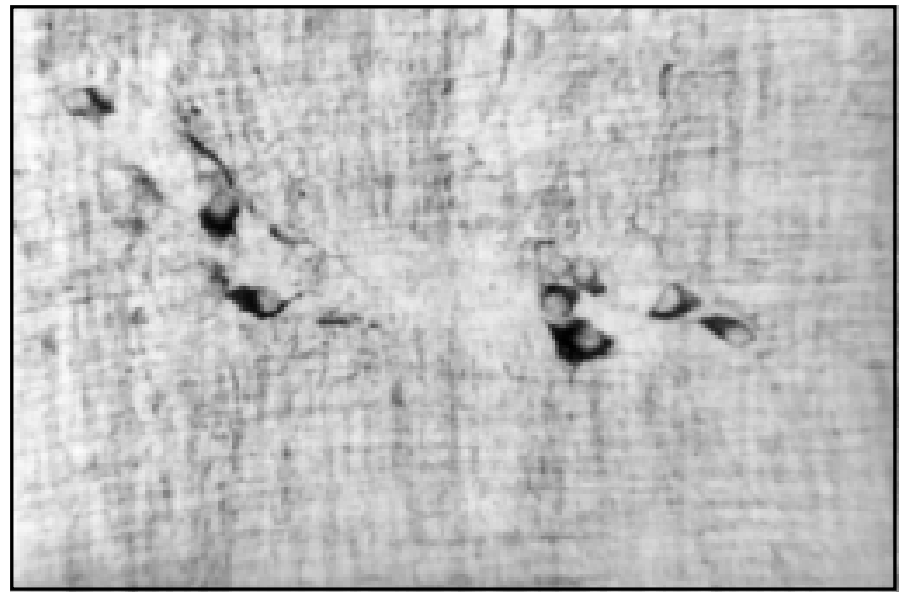

Fig 2. NADH-positive neurons on the intermediate region of the duodenum of a control animal. Green filter, $184 X$.

value $(p=0.0148)$. In proportional terms, the NADH-positive neurons represented $18.54 \%$ of the Giemsa-stained neurons on the control animals and $39.33 \%$ on the diabetic animals.

The mean area of cell body profile of the myenteric neurons on the duodenum of the control animals was $229.7 \pm 3.75 \mu \mathrm{m}^{2}$ and that of the nuclear profile was $88.02 \pm 1.23 \mu \mathrm{m}^{2}$. These areas were not significantly different from those of the diabetic animals, where the corresponding values were $224.0 \pm 3.88 \mu \mathrm{m}^{2}$ and $86.52 \pm 1.23 \mathrm{~m}^{2}(\mathrm{p}=0.2911$ for cell body area and $\mathrm{p}=0.3887$ for nuclear area).

\section{DISCUSSION}

Streptozotocin is being increasingly used in experimental procedures as diabetogenic agent. Its mode of action and its potential are still subjects of research and assays. In this study, it was observed that streptozotocin caused a consistent diabetic state on the animals, although plasma

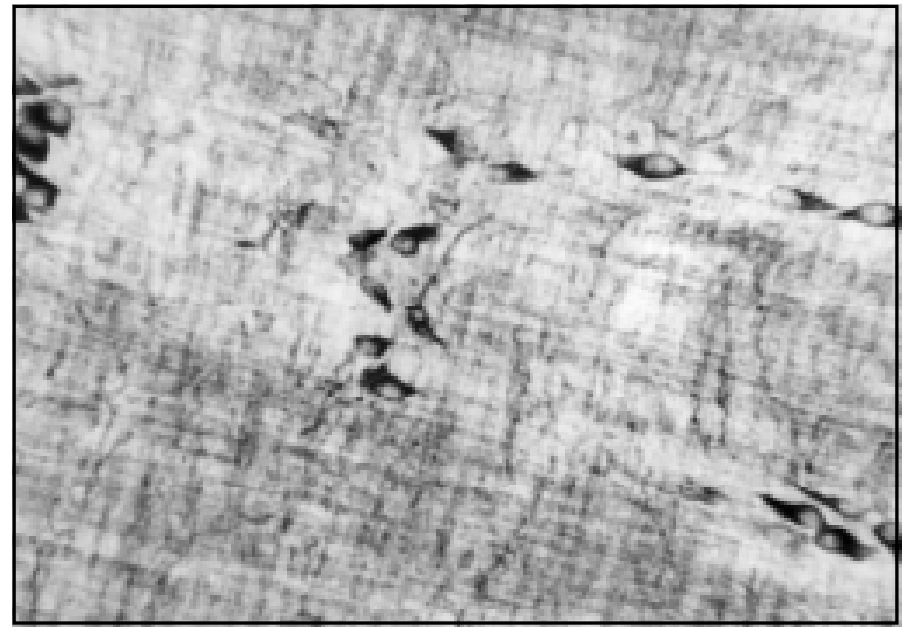

Fig 3. NADH-positive neurons on the intermediate region of the duodenum of a diabetic animal. Green filter, $184 X$. 
glucose level $(214.4 \mathrm{mg} / \mathrm{dl})$ has not been markedly elevated, contrary to the observations made with the same dose of the drug applied to rats aging 75 days and kept diabetic for periods of two and eight months ${ }^{21}$. Studies about the dose-response relationship of streptozotocin discuss that blood glucose levels vary during the first weeks after diabetes induction ${ }^{22}$, which can explain the relatively low glycemic levels observed in this study.

The number of Giemsa-stained myenteric neurons found on the duodenum of the control animals is about $38 \%$ smaller than that reported by Buttow et al. ${ }^{23}$, with values corrected for differences on the counting areas. The explanation is based on the difference of age between the rats: while the animals of this study had seven months of age, those had three and five months on the sacrifice. This decrease on the neuronal population is also described by other authors on the intestine of rats ${ }^{15}$ and guinea-pigs ${ }^{24}$, and on the small and large intestines of humans ${ }^{25,26}$, and is due to aging by itself, independently of pathophysiological conditions.

In spite of the diabetic animals exhibiting fewer Giemsa-stained neurons than the controls, the difference between counts did not attain significance. On the other hand, there are reports of aproximately $18 \%$ decrease on the number of myenteric neurons in the duodenum of diabetic rats ${ }^{23}$. It must be stressed, however, that those authors used the same dose of streptozotocin but in considerably younger animals (mean weight of $250 \mathrm{gr}$ and 75 days of age). Considering that peripheral nerves of rats are more suscetible to morphological and physiological changes until the $26^{\text {th }}$ week of age $^{27}$, it is possible that the myenteric plexus of younger rats is more sensitive to experimental diabetes than that of mature ones.

Opposite to what was observed on the Giemsa-stained neurons, the number of NADH-positive neurons increased substantially on the diabetic animals, rising the proportion of this neuronal subpopulation, relative to the Giemsa-stained population, from $18.54 \%$ on the controls to $39.33 \%$ on the diabetics. On the literature, there are reports stating that high glycemic levels ${ }^{28,29}$ and their metabolic and vascular consequences ${ }^{30}$ are the cause of an increased NADH/NAD ${ }^{+}$ratio, which influences the activity of the enzymes using these cofactors ${ }^{28}$. In this way, it is possible that the greater neuronal reactivity observed in this study was due to a greater activity of the enzyme(s) involved on the evidenciation of these cells by the NADH-diaphorase technique, elicited during the experimental period by the hyperglycemic state, and not by streptozotocin, once the glucose uptake by neurons is insulin-independent, and thus is a function of the plasma concentration of the substance. On the hepatic cells, which are also insulin-independent for glucose uptake, it was observed that in periods of diabetes from five days to eight months, the relationship NADH/NAD is always changed and probably irreversibly ${ }^{29}$. The disponibility of substrates and the reaction time during incubation of the segments can both be discarded as cause of the greater neuronal reactivity on the diabetic animals, because incubation medium contained, in equal amounts for both groups, the substrates nitro blue tetrazolium (NBT) and $\beta-\mathrm{NADH}$, and all segments were identically processed.

In humans whose plasma glucose levels reach between 300 and $500 \mathrm{mg} / \mathrm{dl}$, the glucose loss on the urine is considered as causing extra- and intracellular dehydration ${ }^{31}$. In this study, the morphometric analyses of the areas of cell body and nucleus profiles of the myenteric neurons did not demonstrate a statistically significant difference between the control and diabetic groups, although on the latter the neurons and their nuclei had been marginally smaller. The lack of difference on the morphometry of these cells can be related to the glycemic level which, despite being above normal, was below that observed in chronically-diabetic animals ${ }^{21}$, and thus was not high enough to elicit an intracellular dehydration capable of affecting the dimensions of the myenteric neurons and their nuclei.

\section{CONCLUSIONS}

1) In mature adult rats, streptozotocin-induced diabetes does not provoke significant decrease on the duodenal neuronal population during the one-week period. 
2) On the streptozotocin-induced diabetes, there is an increase on the respiratory metabolism of the myenteric neurons, rising the proportion of neurons evidenced by the NADH-diaphorase.

3) Moderate plasma glucose levels in diabetic rats are not sufficient to induce intracellular dehydration capable of significantly reducing the size of the myenteric neurons and their nuclei.

Aknowledgements - The authors thank Mr. José Antônio de Souza and Mrs. Maria Ap. P. Agostinho for the technical support.

\section{REFERENCES}

1. Irwin DA. The anatomy of Auerbach's plexus. Am J Anat 1931;49:141-165.

2. Gabella G. Innervation of the gastrointestinal tract. Int Rev Cytol 1979;59:129-193.

3. Gabella G. The number of neurons in the small intestine of mice, guinea-pigs and sheep. Neuroscience 1987;22:737-752.

4. Ekblad E, Winther C, Ekman R, Hakanson R, Sundler F. Projections of peptide-containing neurons in rat small intestine. Neuroscience 1987;20:169-188.

5. Ekblad E, Ekman R, Hakanson R, Sundler F. Projections of peptide-containing neurons in rat colon. Neuroscience 1988;27:655-674.

6. Karaosmanoglu T, Aygun B, Wade PR, Gershon MD. Regional differences in the number of neurons in the myenteric plexus of the guinea pig small intestine and colon: an evaluation of markers used to count neurons. Anat Rec 1996;244:470-480.

7. Costa M, Brookes SJH. The enteric nervous system. Am J Gastroenterol 1994;89:S129-S137.

8. Costa M, Brookes SJH, Steele PA, Gibbins I, Burcher E, Kandiah CJ. Neurochemical classification of myenteric neurons in the guinea-pig ileum. Neuroscience 1996;75:949-967.

9. Sang Q, Williamson S, Young HM. Projections of chemically identified myenteric neurons of the small and large intestine of the mouse. J Anat 1997;190:209-222.

10. Lincoln J, Bokor JT, Crowe R, Griffith SG, Haven AJ, Burnstock G. Myenteric plexus in streptozotocin-treated rats; neurochemical and histochemical evidence for diabetic neuropathy in the gut. Gastroenterology 1984;86:654-661.

11. Belai A, Lincoln J, Milner P, Crowe R, Loesch A, Burnstock G. Enteric nerves in diabetic rats: increase in vasoactive intestinal polypeptide but not substance P. Gastroenterology 1985;89:967-976.

12. Belai A, Lincoln J, Milner P, Burnstock G. Differential effect of streptozotocin-induced diabetes on the innervation of the ileum and distal colon. Gastroenterology 1991;100:1024-1032.

13. Belai A, Calcutt NA, Carrington AL, Diemel LT, Tomlinson DR, Burnstock G. Enteric neuropeptides in streptozotocindiabetic rats; effects of insulin and aldose reductase inhibition. J Auton Nerv Syst 1996;58:163-169.

14. Gabella G. Neuron size and number in the myenteric plexus of the newborn and adult rat. J Anat 1971;109:81-95.

15. Santer RM, Baker DM. Enteric neuron numbers and sizes in Auerbach's plexus in the small and large intestine of adult and aged rats. J Auton Nerv Syst 1988;25:59-67.

16. Schusser GF, White NA. Morphologic and quantitative evaluation of the myenteric plexuses and neurons in the large colon of horses. J Am Vet Med Assoc 1997;210:928-934

17. Sant'Ana DMG, Miranda-Neto MH, Molinari SL, Sant'Ana MA. Neuron number in the myenteric plexus of the ascending colon of rats; a comparative study using two staining techniques. Arq Neuropsiquiatr 1997;55:460-466.

18. Fregonesi CEPT, Miranda-Neto MH, Molinari SL. Estudo morfológico e quantitativo do corpo do estômago de Rattus norvegicus. Acta Scientiarum 1998;20:221-224.

19. Barbosa AJA. Técnica histológica para gânglios nervosos intramurais em preparados espessos. Rev Bras Pesq Med Biol 1978;11:95-97.

20. Gabella G. Detection of nerve cells by a histochemical technique. Experientia 1969;25:218-219.

21. Zanoni JN, Miranda-Neto MH, Bazotte RB, de Souza RR. Morphological and quantitative analysis of the neurons of the myenteric plexus of the cecum of streptozotocin-induced diabetic rats. Arq Neuropsiquiatr 1997;55:696-702.

22. Junod A, Lambert AE, Stauffacher W, Renold AE. Diabetogenic action of streptozotocin: relationship of dose to metabolic response. J Clin Invest 1969:48:2129-2139.

23. Büttow NC, Miranda-Neto MH, Bazotte RB. Morphological and quantitative study of the myenteric plexus of the duodenum of streptozotocin-induced diabetic rats. Arq Gastroenterol 1997;34:34-42.

24. Gabella G. Fall in the number of myenteric neurons in aging guinea pigs. Gastroenterology 1989;96:1487-1493.

25. Souza RR, Moratelli HB, Borges N, Liberti EA. Age-induced nerve cell loss in the myenteric plexus of the small intestine in man. Gerontology 1993;39:183-188.

26. Gomes OA, Souza RR, Liberti EA. A preliminary investigation of the effects of aging on the nerve cell number in the myenteric ganglia of the human colon. Gerontology 1997;43:210-217.

27. Malone JI, Lowitt S, Korthals JK, Salem A, Miranda C. The effect of hyperglicemia on nerve conduction and structure is age dependent. Diabetes 1996;45:209-215.

28. Enden MK, Nyengaard JR, Ostrow E, Burgan JH, Williamson JR. Elevated glucose levels increase retinal glicolysis and sorbitol pathway metabolism; implications for diabetic neuropathy. Invest Ophthalmol Vis Sci 1995;36:1675-1685.

29. Ferraz M, Brunaldi K, Oliveira CE, Bazotte RB. Hepatic glucose production from L-alanine is absent in perfused liver of diabetic rats. Res Commun Molec Pathol Pharmacol 1997;95:147-156.

30. Stevens MJ, Feldman EL, Greene DA. The aetiology of diabetic neuropathy: the combined roles of metabolic and vascular defects. Diabetic Med 1995;12:566-579.

31. Guyton AC, Hall JE. Textbook of medical physiology. 9.Ed. Philadelphia: W.B. Saunders, 1996. 